E-Prodenta Journal of Dentistry. 2019. 3(1): 208-215

DOI : http://dx.doi.org/10.21776/ub.eprodenta.2019.003.01.4

\title{
PENGARUH BAHAN BLEACHING HIDROGEN PEROKSIDA 35\% TERHADAP KEKASARAN PERMUKAAN RESIN KOMPOSIT NANOHYBRID
}

\author{
Yuliana Ratna Kumala*, Faidah*, Sita Silvia Harsari** \\ *Departemen Konservasi Gigi Fakultas Kedokteran Gigi Universitas Brawijaya \\ **Program Studi Sarjana Kedokteran Gigi Fakultas Kedokteran Gigi Universitas Brawijaya \\ Korespondensi : Yuliana Ratna Kumala, Email : malapdgub@gmail.com
}

\begin{abstract}
ABSTRAK
Teknik in office bleaching merupakan salah satu teknik pemutihan gigi yang dilakukan oleh dokter gigi ditempat praktek. Aplikasi bahan in office bleaching tidak hanya mempunyai efek terhadap jaringan gigi, tetapi juga mempunyai efek pada tumpatan gigi, seperti resin komposit nanohybrid. Tujuan: untuk meneliti pengaruh bahan in office bleaching hidrogen peroksida $35 \%$ terhadap kekasaran permukaan resin komposit nanohybrid dengan berat matriks yang berbeda. Metode: yang digunakan adalah true experimental design menggunakan 32 sampel resin komposit yang dibagi menjadi 2 kelompok, yaitu kelompok A dan kelompok B. Kelompok A merupakan resin komposit nanohybrid dengan berat matriks 22,5 wt \% dan kelompok B merupakan resin komposit nanohybrid dengan berat matriks $19 \mathrm{wt} \%$. Setiap kelompok terdiri dari 16 sampel. Kedua kelompok tersebut direndam dalam saliva buatan dan dimasukkan kedalam inkubator dengan suhu $37^{\circ} \mathrm{C}$ selama 24 jam. Kemudian kedua sampel tersebut diaplikasikan bahan bleaching hidrogen peroksida $35 \%$ selama 30 menit. Kekasaran permukaan resin komposit nanohybrid diukur menggunakan Surface Roughness Tester. Uji statistik yang digunakan adalah uji normalitas, uji homogenitas, uji Paired T-Test dan uji Independent T-Test. Hasil: analisis data dengan uji statistik Paired T-Testmenunjukkan ada pengaruh yang signifikan pada kekasaran permukaan resin komposit nanohybrid sebelum dan sesudah aplikasi bahan in office bleaching hidrogen peroksida $35 \%$ pada kelompok $A(p=0,000)$ dan kelompok $B(p=$ $0,000)$. Kesimpulan: dari penelitian ini adalah terdapat pengaruh aplikasi bahan in office bleaching hidrogen peroksida $35 \%$ terhadap kekasaran permukaan resin komposit nanohybrid dengan berat matriks yang berbeda.
\end{abstract}

Kata kunci : Resin komposit nanohybrid, kekasaran permukaan, in office bleaching. 


\title{
EFFECT OF 35\% HYDROGEN PEROXIDE BLEACHING ON NANOHYBRID COMPOSITE RESINS SURFACE ROUGHNESS
}

\begin{abstract}
In office bleaching is one of the teeth whitening techniques, performed by dentist in dental practices. Application of bleaching agent is not only have an effect on the tooth tissue, but also have an effect on restorative nanohybrid dental composite resins. Purpose: of this research is to understand the effect of in office bleaching material 35\% hydrogen peroxide on the surface roughness of nanohybrid composite resin with different matrix weight. Method: true experimental design using 32 samples of nanohybrid resin composites that were divided into two groups, there are group $A$ and group B. Group $A$ is nanohybrid resin composite with 22,5 wt \% matriks weight and group $B$ is nanohybrid resin composite with 19 wt \% matriks weight. Each group contains 16 samples of nanohybrid composite resin. Both of the groups were immersed in artificial saliva and put into an incubator with a temperature of $37^{\circ} \mathrm{C}$ for 24 hours. Then both of the samples were applied with 35\% hydrogen peroxide bleaching agent for 30 minutes. The surface roughness of nanohybrid resin composite before and after treatment were measured using surface roughness tester. The data were analyzed with normality test, homogeneity test, Paired Sample T-Test, and Independent T-Test, respectively. Result: The Paired TTest analysis on each groups shows that there are significant changes in surface roughness of nanohybrid composite resin before and after application of in office bleaching agent hydrogen peroxide $35 \%$ in group $A(p=0,000)$ and group $B(p=0,000)$. Conclusion: the application of in office bleaching agent $35 \%$ hydrogen peroxide effects the surface roughness of nanohybrid composite resin with different matrix weight.
\end{abstract}

Keyword : Nanohybrid composite resin, surface roughness, in office bleaching.

\section{PENDAHULUAN}

Kesadaran masyarakat akan pentingnya estetik semakin meningkat. Gigi merupakan salah satu faktor estetika yang penting bagi pasien, termasuk warna gigi. Gigi yang mengalami perubahan warna dapat menurunkan rasa percaya diri dan mengurangi keindahan penampilan ${ }^{1}$. Dental bleaching merupakan salah satu perawatan yang sukses dan diterima dengan baik untuk gigi yang mengalami diskolorisasi².
Terdapat dua metode pemutihan gigi vital, yaitu dikerjakan di tempat praktik dokter gigi (in office bleaching) dan dilakukan dirumah (home bleaching). Pada metode in office bleaching digunakan bahan hidrogen peroksida dengan konsentrasi yang tinggi 25\%-40\% dan diaplikasikan selama 30-40 menit ${ }^{3}$. Aplikasi bahan bleaching hidrogen peroksida 35\% selama 30 menit pada teknik in office bleaching disarankan karena efektif dan hanya 
menyebabkan sedikit perubahan kekerasan enamel ${ }^{4}$.

Restorasi komposit sering ditemukan pada gigi-gigi yang akan dilakukan perawatan bleaching, baik gigi anterior maupun posterior ${ }^{5}$. Jenis resin komposit yang terbaru dan banyak digunakan pada saat ini adalah resin komposit nanohybrid karena memiliki kelebihan, yaitu dapat digunakan pada tumpatan anterior maupun posterior karena memiliki sifat-sifat fisik dan mekanik yang baik, serta estetika yang baik ${ }^{6}$. Walaupun memiliki kelebihan, polimer pada resin komposit mengandung ikatan yang tidak stabil, sehingga mudah terdegradasi, misalnya oleh bahan dengan $\mathrm{PH}$ rendah atau asam yang dapat mempengaruhi kekasaran permukaan resin komposit? ${ }^{7}$.

Radikal bebas yang dihasilkan oleh hidrogen peroksida memiliki sifat reaktif yang dapat mendegradasi matriks organik resin komposit sehingga dapat menyebabkan kekasaran permukaan resin komposit ${ }^{8}$. Berat matriks organik dari resin komposit menentukan peningkatan kekasaran permukaan yang terjadi. Semakin berat matriksnya semakin mudah terdegradasi sehingga semakin besar peningkatan kekasaran permukaannya9 .

Kekasaran permukaan resin komposit berpengaruh terhadap estetik dan perubahan warna pada restorasi, akumulasi plak dan zat warna makanan atau minuman dapat menempel pada permukaan restorasi sehingga menyebabkan perubahan warna pada restorasi tersebut. Perubahan warna pada resin komposit akan menjadi pertimbangan apakah restorasi yang sudah berubah warna tersebut perlu diganti baru atau tetap dipertahankan ${ }^{10}$.
Menurut Sadighe et al (2014) menyatakan bahwa aplikasi bahan in office bleaching hidrogen peroksida $40 \%$ dapat menyebabkan penurunan kekerasan permukaan resin komposit nanohybrid secara signifikan ${ }^{11}$. Penelitian lain juga menyatakan bahwa aplikasi bahan home bleaching karbamid peroksida $10 \%$ dan 20\% tidak menyebabkan kekasaran permukaan resin komposit nanohybrid ${ }^{12}$. Maka penulis melakukan penelitian untuk mengetahui pengaruh bahan in office bleaching hidrogen peroksida $35 \%$ terhadap kekasaran permukaan resin komposit nanohybrid dengan berat matriks yang berbeda.

\section{METODE}

1. Rancangan Penelitian. Penelitian ini menggunakan metode true experimental design (penelitian eksperimental murni) dengan pendekatan pre and post test control group design.

2. Sampel Penelitian. Sampel yang digunakan pada penelitian ini adalah resin komposit nanohybrid dengan berat matriks 22,5 wt \% dan 19 wt \% wt dengan ukuran diameter $5 \mathrm{~mm}$ dan tinggi $2 \mathrm{~mm}$ sebanyak 32 sampel.

3. Variabel Penelitian. Variabel bebas pada penelitian ini adalah bahan in office bleaching hidrogen peroksida 35\%. Variabel terikat adalah resin komposit nanohybrid.

\section{Prosedur Penelitian}

\section{a. Tahap persiapan.}

Cetakan dibuat dengan menggunakan sedotan dengan diameter $5 \mathrm{~mm}$ dipotong dengan tinggi $2 \mathrm{~mm}$. Celluloid strip diletakkan diatas glass lab terlebih dahulu. Label plastik 
kecil diletakkan pada dasar cetakan di atas celluloid strip. Bahan resin komposit diaplikasikan ke dalam cetakan yang diletakkan diatas glass lab dan celluloid strip. Cetakan difiksasi dengan menggunakan pinset kedokteran gigi. Resin komposit Gambar 2. Polimerisasi resin komposit nanohybrid dikondensasikan dengan filling instrument logam. Satu lembar celluloid strip diletakkan di atas resin komposit yang telah dimampatkan ${ }^{13}$.

Bahan resin komposit tersebut lalu ditindih dengan glass lab di atasnya agar kelebihan bahan akan meluber keluar cetakan dan akan diperoleh lempengan resin komposit yang rata dan mampat. Glass lab diambil dan kelebihan bahan dibersihkan, lalu resin komposit dipolimerisasikan menggunakan light curing unit selama 40 detik dengan jarak $1 \mathrm{~mm}^{14}$. Setelah dipolimerisasi, bahan dikeluarkan dari dalam cetakannya.

Setelah itu sebanyak 32 sampel dibagi menjadi 2 kelompok. Kelompok $A$ adalah resin komposit nanohybrid dengan berat matriks $22,5 \%$. Kelompok B adalah resin komposit nanohybrid dengan berat matriks $19 \%$.

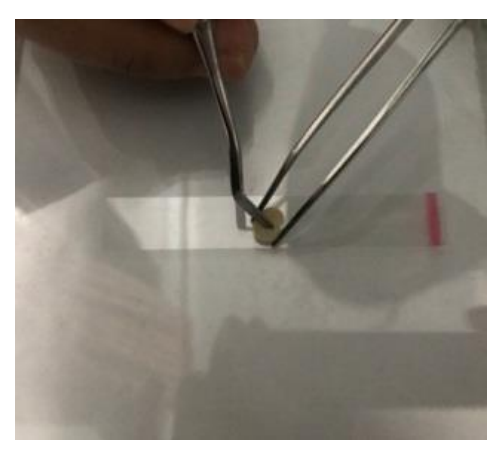

Gambar 1. Pengaplikasian resin komposit nanohybrid ke dalam cetakan



\section{b. Tahap Pelaksanaan.}

Resin komposit nanohybrid direndam dalam saliva buatan masing-masing 10 lempeng resin komposit dalam wadah plastik dan ditutup rapat. Semua sampel yang diuji dimasukan ke inkubator dengan suhu $37^{\circ} \mathrm{C}$ selama 24 jam. Setelah perlakuan selesai, lempeng resin komposit kedua kelompok tersebut dikeringkan dengan menggunakan tissue. Kemudian kekasaran permukaan diukur menggunakan alat Surface Roughness Tester merk Mitutoyo tipe SJ -210, Jepang. Bahan in office bleaching hidrogen peroksida 35\% diaplikasikan pada seluruh sampel selama 30 menit. Sampel dibilas dengan aquades steril untuk menghilangkan bahan bleaching. Kemudian kekasaran permukaan diukur kembali menggunakan alat Surface Roughness Tester.

\section{c. Analisis Data.}

Data kekasaran permukaan dianalisis dengan menggunakan uji normalitas dan uji homogenitas. Apabila data telah terdistribusi normal dan homogen, maka dilakukan uji Paired Sample T-Test untuk mengetahui pengaruh sebelum dan sesudah aplikasi bahan in office bleaching hidrogen peroksida 35\%, lalu dilakukan uji Independent Sample T-Test untuk mengetahui perbedaan antara dua kelompok.

\section{HASIL PENELITIAN}


Setiap sampel telah diuji dan dicatat masing-masing nilai kekasaran permukaannya sebelum dan sesudah aplikasi bahan in office bleaching hidrogen peroksida 35\%.

Diagram 1. Perubahan nilai rata-rata kekasaran permukaan resin komposit sebelum dan sesudah aplikasi bahan in office bleaching hidrogen peroksida $35 \%$

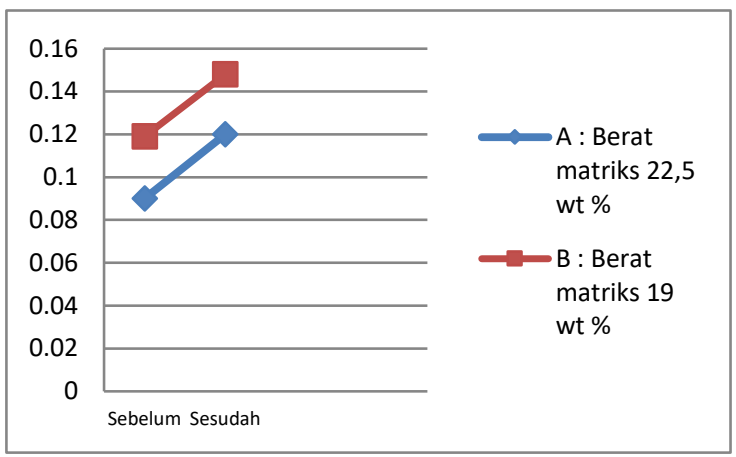

Diagram 2. Selisih nilai rata-rata kekasaran permukaan resin komposit nanohybrid sebelum dan sesudah aplikasi bahan in office bleaching hidrogen peroksida $35 \%$

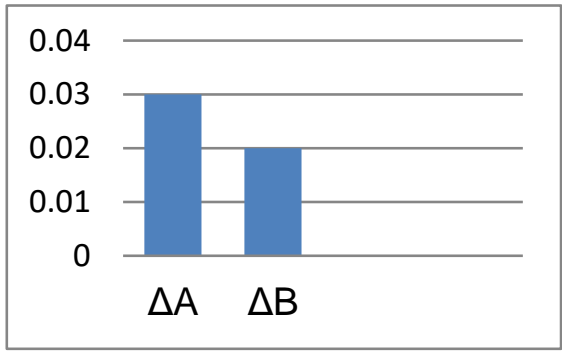

Pada diagram 1 menunjukkan bahwa nilai rata-rata kekasaran permukaan resin komposit kelompok A sebelum dan sesudah aplikasi bahan in office bleaching hidrogen peroksida $35 \%$, yaitu 0,09 $\mu \mathrm{m}$ dan 0,12 $\mu \mathrm{m}$. Sedangkan nilai rata-rata kekasaran permukaan resin komposit kelompok B sebelum dan sesudah aplikasi bahan in office bleaching hidrogen peroksida 35\%, yaitu $0,12 \mu \mathrm{m}$ dan $0,14 \mu \mathrm{m}$. Pada diagram 2 menunjukkan selisih nilai rata- rata kekasaran permukaan resin komposit nanohybrid sebelum dan sesudah aplikasi bahan in office bleaching hidrogen peroksida 35\% pada kelompok A yaitu 0,03 lebih besar daripada kelompok B yaitu 0,02.

Data yang diperoleh dari penelitian ini kemudian dilakukan analisis data statistik.

Tabel 1. Selisih rata-rata kekasaran permukaan resin komposit nanohybrid $(\mu \mathrm{m})$ sebelum dan sesudah aplikasi bahan in office bleaching

\begin{tabular}{ccc}
\hline Kelompok & $\mathrm{N}$ & Mean \pm SD \\
\hline Delta A & 16 & $0,0304 \pm 0,0262$ \\
Delta B & 16 & $0,0289 \pm 0,0262$ \\
\hline
\end{tabular}

Tabel 2. Hasil uji paired t-test kelompok A

\begin{tabular}{cccc}
\hline \multicolumn{4}{c}{ Paired Sampel Test } \\
\hline & T & Df & $\begin{array}{l}\text { Sig (2- } \\
\text { tailed) }\end{array}$ \\
\hline Pair A & -4.640 & 15 & 0,000 \\
\hline
\end{tabular}

Tabel 3. Hasil uji paired $t$-test kelompok B

\begin{tabular}{cccc}
\hline \multicolumn{4}{c}{ Paired Sampel Test } \\
\hline & T & Df & $\begin{array}{c}\text { Sig (2- } \\
\text { tailed) }\end{array}$ \\
\hline Pair B & $-4,775$ & 15 & 0,000 \\
\hline
\end{tabular}

Tabel 4. Hasil uji Independent Sample T-Test

\begin{tabular}{|c|c|c|c|}
\hline \multicolumn{4}{|c|}{ T-Test For Equality Mean } \\
\hline & $T$ & Df & $\begin{array}{l}\text { Sig (2- } \\
\text { tailed) }\end{array}$ \\
\hline $\begin{array}{c}\text { Delta equal } \\
\text { varian } \\
\text { assumed }\end{array}$ & 0,168 & 30 & 0,868 \\
\hline $\begin{array}{c}\text { equal } \\
\text { varian } \\
\text { not } \\
\text { assumed }\end{array}$ & 0,168 & 29,833 & 0,868 \\
\hline
\end{tabular}


Pada tabel 1 menunjukkan bahwa ratarata peningkatan kekasaran permukaan resin komposit kelompok A lebih tinggi dari kelompok B. Pada tabel 2 dan 3 menunjukkan hasil uji Paired Sampel T-Test untuk kelompok A $p=0,000$ dan untuk kelompok $B p=0,000$, sehingga dapat diartikan terdapat pengaruh yang bermakna pada kekasaran permukaan resin komposit nanohybrid setelah dilakukan aplikasi bahan in office bleaching hidrogen peroksida 35\%. Berdasarkan hasil uji independent sample t-test pada tabel 4 didapatkan hasil $p=0,868$ yang menunjukkan tidak ada perbedaan bermakna pada kedua kelompok.

\section{Pembahasan}

Hasil penelitian menunjukkan terdapat perubahan data kekasaran permukaan resin komposit nanohybrid yang signifikan pada kedua kelompok sebelum dan sesudah aplikasi bahan in office bleaching hidrogen peroksida $35 \%$. Peningkatan kekasaran permukaan resin komposit nanohybrid pada kelompok A dan B dapat terjadi karena adanya radikal bebas yang dihasilkan oleh bahan bleaching hidrogen peroksida dapat mendegradasi matriks resin komposit.

Radikal bebas yang dihasilkan oleh bahan bleaching hidrogen peroksida adalah perihidroksil $\left(\mathrm{HO}_{2}\right)$ yang merupakan radikal bebas kuat dan oksigenase $\left(\mathrm{O}^{-}\right)$yang merupakan radikal bebas lemah ${ }^{14}$. Perihidroksil dapat menyebabkan degradasi pada monomer UDMA, TEGDMA dan Bis-EMA yang terdapat pada resin komposit nanohybrid ${ }^{5}$. Proses degradasi dari polimer resin komposit nanohybrid diawali dengan radikal bebas kuat perihidroksil dari bahan bleaching yang berdifusi ke dalam rantai polimer. Lalu ikatan rantai polimer akan melunak dan rusak sehingga menyebabkan monomer dari matriks resin komposit terlepas. Ketika monomer matriks resin terlepas, akan terjadi perubahan mikrostruktur dari resin komposit. Perubahan mikrostruktur resin komposit akan menghasilkan porus permukaan yang akan menyebabkan kekasaran permukaan pada resin komposit nanohybrid ${ }^{16}$.

Hasil uji Independent Sample T-Test menunjukkan tidak terdapat perbedaan yang signifikan antara kelompok A dan kelompok B setelah diaplikasikan bahan in office bleaching hidrogen peroksida 35\%. Peningkatan kekasaran permukaan resin komposit kelompok A sedikit lebih besar, yaitu sebesar 0,03 $\mu \mathrm{m}$ dibandingkan kekasaran permukaan resin komposit kelompok B, yaitu sebesar 0,02 $\mu \mathrm{m}$. Hal ini disebabkan berat matriks dari kedua resin komposit nanohybrid tersebut berbeda.

Jumlah berat matriks dari resin komposit menentukan seberapa besar peningkatan kekasaran permukaan dari resin komposit nanohybrid. Resin komposit nanohybrid kelompok A memiliki berat matriks 22,5 wt \%. Sedangkan resin komposit nanohybrid kelompok B memiliki berat matriks 19-20 wt \%. Resin komposit dengan jumlah berat matriks lebih banyak lebih mudah menyerap bahan bleaching sehingga degradasi matriks lebih besar dan menyebabkan kekasaran permukaan lebih besar. Hal ini disebabkan karena matriks dari resin komposit bersifat hidrofilik / menyerap cairan ${ }^{17}$.

\section{Kesimpulan}


Terdapat pengaruh bahan in office bleaching hidrogen peroksida 35\% terhadap kekasaran permukaan pada kedua resin komposit nanohybrid dengan berat matriks yang berbeda.

\section{Saran}

1. Perlu dilakukan penelitian lebih lanjut mengenai pengaruh aplikasi bahan in office bleaching hidrogen peroksida 35\% terhadap sifat fisik resin komposit nanohybrid yang lain.

2. Perlu dilakukan penelitian lebih lanjut mengenai pengaruh aplikasi bahan in office bleaching hidrogen peroksida dengan konsentrasi yang berbeda terhadap kekasaran permukaan resin komposit nanohybrid.

3. Disarankan bagi dokter gigi menggunakan bahan restorasi resin komposit nanohybrid sebelum melakukan perawatan in office bleaching hidrogen peroksida 35\% karena memiliki nilai dibawah ambang batas kekasaran permukaan.

\section{DAFTAR PUSTAKA}

1. Fauziah, Cut, Fitriyani Sri, Viona Diansari. Colour change of enamel after application of averrhoa bilimbi. Jurnal of Dentistry Indonesia. 2012; 19(3) : 53-6.

2. Tin-Oo MM, Saddki N, Hassan N. Factors influencing patient saticfaction with dental appearance and treatments they desireto improve aesthetics. BMC Oral Healt. 2011; 11(6): 806-13.

3. Tjuatja, L., Mulyawati, E., Halim, F.S. Perbedaan kekerasan mikro permukaan resin komposit mikrofil dan nanofil pada penggunaan bahan karbamid peroksida $45 \%$ dan hidrogen peroksida 38\% secara in office bleaching. J Ked Gigi. 2011; 2(4): 264-270.

4. $A B$ Borges, RF Zanatta, ACSM Barros, LC Silva, CR Pucci, CGR Torres. Effect of Hydrogen Peroxide Concentration on Enamel Color and Microhardness. J. Dentonline. 2015; 40(1): 96-101.

5. Wang L, Francisconi LF, Atta MT, Santos JR, Padre NC. Effect of gels on surface roughness of nanofilled composite resins. Eur J Dent. 2011; 5(2): 173-9.

6. Panto, V. Nanohybrid Resin Komposit. 2011; http://repository.usu.ac.id/handle/12 3456789/21456. Diakses 20 Februari 2017.

7. M. Hasriandy Chandra Basri, Isyana Erlita, M. Yanuar Ichrom N. Kekasaran Permukaan Resin Komposit Nanofiller Setelah Perendaman Alam Air Sungai dan Air PDAM. Jurnal Kedokteran Gigi. 2017; 2(1): 101-106.

8. Durner J, Obermaier J, Ilie N. Investigation of different bleaching conditions on the amount of elutable substances from nanohybrid composites. Dent Mter. 2014; 30: 192-9.

9. Sideridou ID, Karabela MM, Vouvoudi Ech. Physical Properties of Current Dental Nanohybrid and Nanofill Light-Cured Resin Composites. Dent Mater. 2011; 27(6): 598607.

10. Praditya Wisang Irwanda., Yulita Kristanti., Sri Daradjati. Perbedaan Perubahan Warna pada Bahan Restorasi Giomer dan Kompomer Pasca Aplikasi Bahan Bleaching Berbahan Dasar Hidrogen Peroksida 40\% 
sebagai Bahan In Office Bleaching. J. Ked Gi. 2016; 7(2): 145-150.

11. Sadighe, Kiana, Mansoore, Mohammad Javad. Effect of $15 \%$ Carbamide Peroxide on the Microhardness and Color Change of Composite Resins. J. Dent. 2014; 11(2): 196-209.

12. Ab-Ghani Zuryati, Ooi Qian Qian, Mohamad Dasmawati. Effect of home bleaching on surface hardness and surface roughness of an experimental nanocomposite. J Conserv Dent. 2013; 16(4): 356-361.

13. Style V, P.S.Anindita, Juliatri. Pengaruh kopi arabika terhadap perubahan warna resin komposit hybrid. Jurnal-e-Gigi. 2017; 5(1): 53-57.

14. Galih Sampoerno. Effectiveness of bleaching agent on composite resin discoloration. Dental Journal. 2012; 45(1): 43-47.

15. Fakriantu Chaldun Pary, Yulita Kristanti, Wignyo Hadriyanto. Pengaruh Karbamid Peroksida 10\% dan 20\% sebagai Bahan Home Bleaching terhadap Perubahan Kekasaran Permukaan Resin Komposit Nanofil dan Giomer. J.Ked Gi. 2015; 6(2): 146-152.

16. R. Helal Soekartono, Anita Yuliati, Ratih Mutiara, Dian Dwi Pratiwi. Sifat fisik permukaan resin komposit hybrid setelah direndam dalam minuman energi ph asam. Jurnal material kedokteran gigi. 2014; 3(1): 8-17.

17. Astrid Yudith., Rusfian., Illice CW. Penyerapan Air dan Kelarutan Resin Komposit Mikrohibrid dan Nanohibrid. 2013; 2(4): 1-5. 